\title{
Along-stream transport and transformation of dissolved organic matter in a large tropical river
}

\author{
Thibault Lambert ${ }^{1}$, Cristian R. Teodoru ${ }^{2}$, Frank C. Nyoni ${ }^{3}$, Steven Bouillon ${ }^{2}$, François Darchambeau ${ }^{1}$, \\ Philippe Massicotte ${ }^{4}$, and Alberto V. Borges ${ }^{1}$ \\ ${ }^{1}$ University of Liège, Chemical Oceanography Unit, Liège, Belgium \\ ${ }^{2}$ KU Leuven, Department of Earth and Environmental Sciences, Leuven, Belgium \\ ${ }^{3}$ University of Zambia, Integrated Water Resources Management Centre, Lusaka, Zambia \\ ${ }^{4}$ Aarhus University, Department of Bioscience, Aarhus, Denmark \\ Correspondence to: Thibault Lambert (tlambert@ulg.ac.be)
}

Received: 10 January 2016 - Published in Biogeosciences Discuss.: 8 February 2016

Revised: 14 April 2016 - Accepted: 29 April 2016 - Published: 10 May 2016

\begin{abstract}
Large rivers transport considerable amounts of terrestrial dissolved organic matter (DOM) to the ocean. However, downstream gradients and temporal variability in DOM fluxes and characteristics are poorly studied at the scale of large river basins, especially in tropical areas. Here, we report longitudinal patterns in DOM content and composition based on absorbance and fluorescence measurements along the Zambezi River and its main tributary, the Kafue River, during two hydrological seasons. During high-flow periods, a greater proportion of aromatic and humic DOM was mobilized along rivers due to the hydrological connectivity with wetlands, while low-flow periods were characterized by lower DOM content of less aromaticity resulting from loss of connectivity with wetlands, more efficient degradation of terrestrial DOM and enhanced autochthonous productivity. Changes in water residence time due to contrasting water discharge were found to modulate the fate of DOM along the river continuum. Thus, high water discharge promotes the transport of terrestrial DOM downstream relative to its degradation, while low water discharge enhances the degradation of DOM during its transport. The longitudinal evolution of DOM was also strongly impacted by a hydrological buffering effect in large reservoirs in which the seasonal variability of DOM fluxes and composition was strongly reduced.
\end{abstract}

\section{Introduction}

The composition, transport and transformation of dissolved organic matter (DOM) in large rivers are key aspects for determining regional and global carbon (C) budgets (Schlesinger and Melack, 1981), the fate of terrigenous DOM flowing to the oceans (del Giorgio and Pace, 2008; Massicotte and Frenette, 2011), the influence of fluvial inputs on DOM biogeochemistry in coastal and oceanic environments (Holmes et al., 2008), and the functioning of inland waters as active pipes with regards to the global $\mathrm{C}$ cycle (Cole et al., 2007; Borges et al., 2015a). Riverine DOM is mainly derived from terrestrial soils (e.g., Weyhenmeyer et al., 2012), but it can also be fueled by sources within the aquatic system (Lapierre and Frenette, 2009; Massicotte and Frenette, 2011). Longitudinal patterns of riverine DOM, in terms of both concentration and composition, are controlled by numerous environmental drivers including connectivity with surrounding wetlands (Battin, 1998; Mladenov et al., 2007), lateral inputs from tributaries (Massicotte and Frenette, 2011) and shifts in dominant land cover (Ward et al., 2015). Once in the aquatic ecosystem, terrestrial DOM is exposed to in-stream processing such as photodegradation (Cory et al., 2007; Spencer et al., 2009), microbial respiration (Amon and Benner, 1996; Fasching et al., 2014), and flocculation (von Wachenfeldt and Tranvik, 2008) that usually operate simultaneously and lead to the removal and the transformation of DOM during its transport (Massicotte and Frenette, 2011; Cawley et al., 2012). The composition 


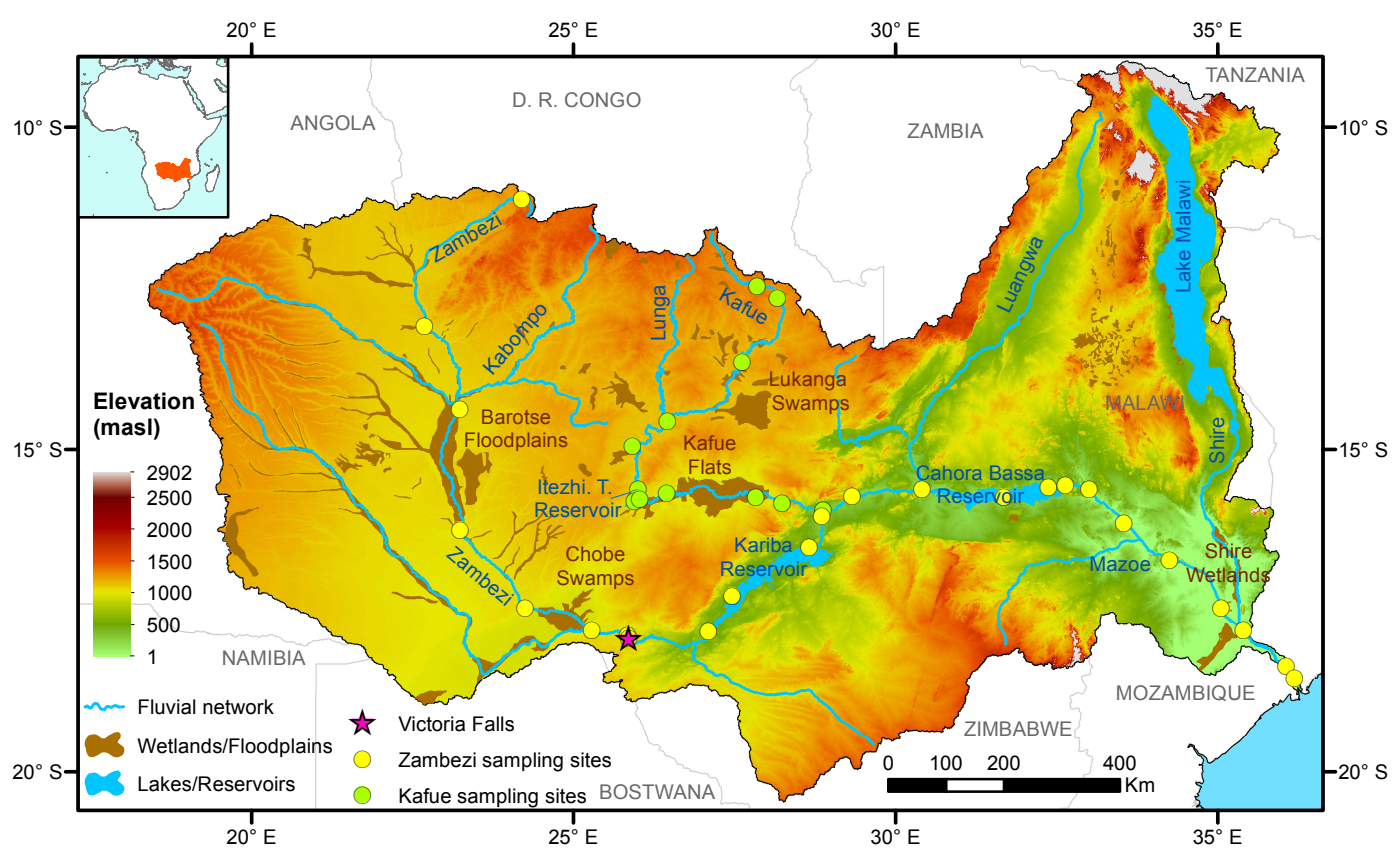

Figure 1. Map of the Zambezi Basin showing elevation, wetlands and floodplains areas (data from Lehner and Döll, 2004), the main hydrological network and the distribution of sampling sites along the Zambezi and the Kafue rivers.

of DOM has been identified as a major driver determining its reactivity in freshwaters (Weyhenmeyer et al., 2012; Kothawala et al., 2014; Kellerman et al., 2015). For example, the selective loss of the colored fraction of terrestrial DOM is a common pattern observed in a wide variety of ecosystems (Moran et al., 2000; Cory et al., 2007; Spencer et al., 2009; Weyhenmeyer et al., 2012). However, aquatic ecosystem properties (e.g., temperature, oxygen availability or composition of aquatic microbial community) may also play an equal role in determining the fate of DOM (MarínSpiotta et al., 2014). Thus, the extent of DOM decay depends on the water residence time (WRT) of the aquatic ecosystem (Cory et al., 2007; Hanson et al., 2011; Köhler et al., 2013). In large rivers, WRT varies spatially, increasing in reservoirs and lakes compared to river channels and seasonally, being higher during low flow compared to high flow. Considering that changes in water level also control the hydrological connectivity with wetlands, it is likely that the downstream gradient in DOM composition drastically differs in relation to spatial and temporal changes in hydrodynamic conditions.

Longitudinal patterns of DOM in large rivers are often assessed in one specific environment, such as wetlands/floodplains (Mladenov et al., 2007; Yamashita et al., 2010; Cawley et al., 2012; Zurbrügg et al., 2013) or lakes (Parks and Baker, 1997; Massicotte and Frenette, 2011; Stackpoole et al., 2014), or limited to a subsection of large rivers (del Giorgio and Pace; 2008; Massicotte and Frenette, 2011; Ward et al., 2015), and mostly carried out during one specific hydrological period. Our understanding of rivers as a continuum in which DOM is simultaneously transported from terrestrial soils to oceans, produced and degraded is thus fundamentally limited by a lack of basin-scale studies taking into account seasonal variations. This is especially true for tropical waters, which have the highest riverine dissolved organic carbon (DOC) flux to the oceans (Meybeck, 1993) but for which DOM cycling has received less attention than rivers in other climate zones, with the exception of the Amazon River (Mayorga et al., 2005; Johnson et al., 2011; Ward et al., 2013, 2015).

The study of DOM biogeochemistry at large spatial and temporal scales requires analytical tools that are simple to implement but have a large sample throughput while providing pertinent information about the DOM chemical composition. Spectroscopic methods, primarily based on ultraviolet-visible and fluorescence measurements, fulfill these criteria (Jaffé et al., 2008). Optical properties of colored DOM (CDOM) and fluorescent DOM (FDOM) can be used to calculate several indices related to DOM composition. These include the specific ultraviolet absorbance at $254 \mathrm{~nm}\left(\mathrm{SUVA}_{254}\right)$, positively related to the degree of DOM aromaticity (Weishaar et al., 2003), the spectral slope ratio $\left(S_{\mathrm{R}}\right)$, inversely related to the average DOM molecular weight (Helms et al., 2008) and the fluorescence index (FI), related to the contribution of terrestrial vs. aquatic microbial inputs (McKnight et al., 2001). FDOM measurements acquired as three-dimensional excitation-emission matrices (EEMs) and coupled with the parallel factor analysis (PARAFAC) provide additional benefits for the characterization of DOM (Stedmon and Markager, 2005; Stedmon et al., 2003; Yamashita et al., 2008). In addition, the carbon stable isotope compo- 


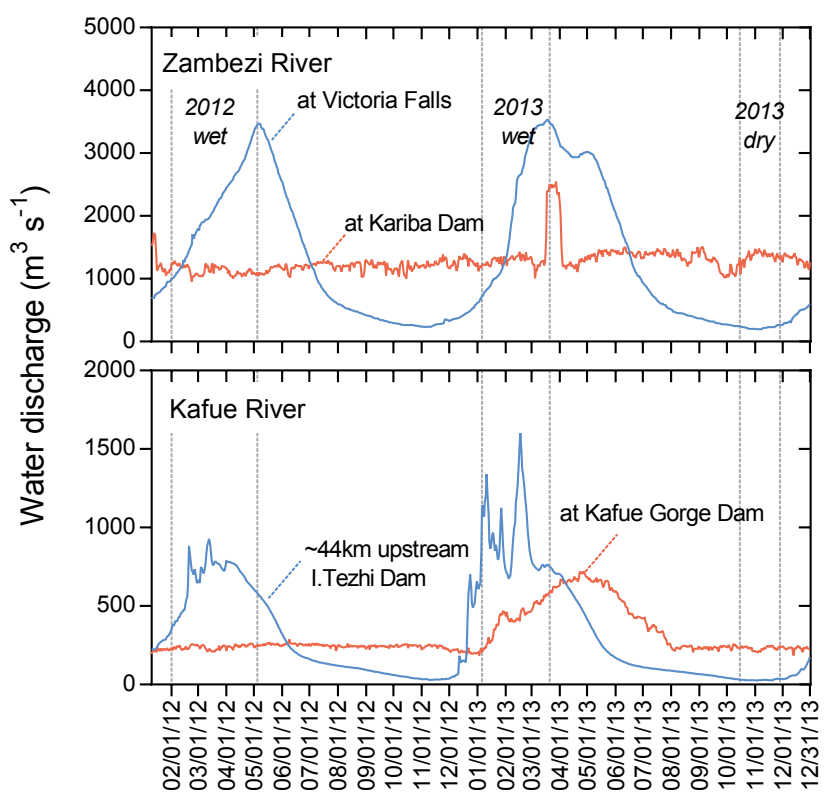

Figure 2. Water discharge between January 2012 and January 2014 for (a) the Zambezi River at Victoria Falls and at Kariba Dam, and (b) for the Kafue River at Hook Bridge located upstream of the Itezhi Tezhi Reservoir and at the Kafue Gorge Dam (data from Zambia Electricity Supply Corporation Limited, ZESCO). Bars refer to the three periods during which field campaigns were performed.

sition of DOC $\left(\delta^{13} \mathrm{C}_{\mathrm{DOC}}\right)$ can provide information about the terrestrial or aquatic origin of DOM (Mladenov et al., 2007; Lambert et al., 2015).

The Zambezi River basin, the fourth largest river in Africa, was extensively sampled from its source to its mouth during three field campaigns carried out over wet and dry seasons (Teodoru et al., 2015; Figs. 1 and 2). Longitudinal patterns of DOM were assessed through measurements of DOC concentrations and characterization of DOM $\left(\delta^{13} \mathrm{C}_{\mathrm{DOC}}\right.$ coupled with CDOM and FDOM) along the Zambezi River $(>3000 \mathrm{~km})$ and its main tributary, the Kafue River $(>1500 \mathrm{~km})$. The aim of this study was to determine the main drivers on downstream patterns of DOM at the scale of a large tropical river, with specific attention to the role of WRT in modulating the fate of DOM.

\section{Materials and methods}

\subsection{Study site}

The Zambezi River has a drainage area of $1.4 \times 10^{6} \mathrm{~km}^{2}$, originates in northwestern Zambia and flows southeast over $3000 \mathrm{~km}$ before it discharges into the Indian Ocean in Mozambique (Fig. 1). The climate of the Zambezi Basin is classified as humid subtropical and is characterized by two main seasons, the rainy season from October/November to April/May and the dry season from May/June to Septem-
ber/October. Annual precipitation strongly varies with latitude, from $>2000 \mathrm{~mm}$ in the northern part and around Lake Malawi to less than $500 \mathrm{~mm}$ in the southern part of the basin. The mean annual rainfall over the entire catchment is $\sim 940 \mathrm{~mm}$ (Chenje, 2000). Up to $95 \%$ of the annual rainfall occurs during the rainy period while the dry period presents irregular and sporadic rainfall events. Consequently, water discharge in Zambezi River has a unimodal distribution with a single maximum peak discharge occurring typically in April/May and a minimum in November (Fig. 2).

Woodlands and shrublands are the dominant $(55 \%)$ land cover and stretch over the whole catchment; forests $(20 \%)$ and grasslands (9\%) areas are mainly confined to the northeast part of the basin and croplands represents $13 \%$ of the total area (Mayaux et al., 2004). Wetlands, including swamps, marshes, seasonally inundated floodplains and mangroves, cover $5 \%$ of the total basin area (Lehner and Döll, 2004).

Based on distinct geomorphological characteristics, the Zambezi Basin can be divided into three major segments: (1) the upper Zambezi from the headwaters to Victoria Falls; (2) the middle Zambezi, from Victoria Falls to the edge of the Mozambique coastal plain (below Cahora Bassa Gorge); and (3) the lower Zambezi, the stretch crossing the coastal plain down to the Indian Ocean (Wellington, 1955). The upper Zambezi covers about $40 \%$ of the total area of the Zambezi Basin but comprises the highest fraction of wetlands and floodplains (about $60 \%$ of the total wetlands/floodplains areas of the Zambezi Basin), including the Barotse Floodplain and the Chobe Swamps (Fig. 1). The middle stretch of the Zambezi River is buffered by two major man-made impoundments, namely the Kariba Reservoir (volume: $167 \mathrm{~km}^{3}$; area: $5364 \mathrm{~km}^{2}$; Magadza, 2010) and the Cahora Bassa Reservoir (volume: $63 \mathrm{~km}^{3}$; area: $2739 \mathrm{~km}^{2}$; Davies et al., 2000). The Kafue River (drainage area: $1.56 \times 10^{5} \mathrm{~km}^{2}$ ) joins the Zambezi River $\sim 70 \mathrm{~km}$ downstream of the Kariba Dam. Similarly to the upper Zambezi, the Kafue River comprises a high density of wetlands/floodplains (about $26 \%$ of the total wetlands/floodplains areas of the Zambezi Basin), including the Lukanga Swamps and the Kafue Flats (Fig. 1). It also comprises two smaller reservoirs, the Itezhi Tezhi Reservoir (volume: $5.4 \mathrm{~km}^{3}$; area: $365 \mathrm{~km}^{2}$; Kunz et al., 2011) and the Kafue Gorge Reservoir (volume: $\sim 1 \mathrm{~km}^{3}$; area: $13 \mathrm{~km}^{2}$; Teodoru et al., 2015). In its lower part, the Zambezi River and its tributary the Shire River both drain narrow but $\sim 200 \mathrm{~km}$ long wetlands areas before their confluence zone. At the end of its course, the river forms a large, $100 \mathrm{~km}$ long floodplaindelta system of swamps and meandering channels.

\subsection{Sampling and analytical methods}

Sampling was conducted during two consecutive years and over two climatic seasons: wet season 2012 (1 February to 5 May, $n=40$ ), wet season 2013 (6 January to 21 March, $n=41$ ), and dry season 2013 (15 October to 28 November, $n=24$; Fig. 2). Sites in the Zambezi and the Kafue rivers 
were located $100-150 \mathrm{~km}$ apart from the spring to the outlet (Fig. 1) except during the 2013 dry season when sampling in the Zambezi River ended before its entrance in the Cahora Bassa Reservoir due to logistical constraints.

Water sampling was mainly performed from boats or dugout canoes in the middle of the river. In few case $(n=10)$, in the absence of boats/canoes, sampling was carried out either from bridges or directly from the shore and as far as possible away from the shoreline, but without discernable effects on the longitudinal patterns on DOM or other biogeochemical variables (Teodoru et al., 2015). Approximately $2 \mathrm{~L}$ of water was collected $0.5 \mathrm{~m}$ below the surface, kept away from direct sunshine and filtered within $2 \mathrm{~h}$ of sampling. The samples preparation for the different analysis was performed just after filtrations. Filtrations were performed successively on pre-combusted $\mathrm{GF} / \mathrm{F}$ glass fiber filters $(0.7 \mu \mathrm{m}$ porosity), then on $0.2 \mu \mathrm{m}$ polyethersulfone syringe filters. Samples for the measurement of DOC concentration and $\delta^{13} \mathrm{C}_{\mathrm{DOC}}$ signatures were stored in $40 \mathrm{~mL}$ glass vials with polytetrafluoroethylene (PTFE)-coated septa with $50 \mu \mathrm{L} \mathrm{H}_{3} \mathrm{PO}_{4}(85 \%)$. Samples for $\mathrm{CDOM} / \mathrm{FDOM}$ analyses were stored in $20 \mathrm{~mL}$ amber glass vials with PTFE-coated septa but without $\mathrm{H}_{3} \mathrm{PO}_{4}$ addition. Samples for major elements (including $\mathrm{Fe}$ ) were stored in $20 \mathrm{~mL}$ scintillation vials and acidified with $50 \mu \mathrm{L}$ of $\mathrm{HNO}_{3}$ (65\%) prior to analysis. Samples were brought back to Belgium for analysis. For logistical reasons, it was not possible to store the samples cold, but the effects of room-temperature storage over several months on samples collected using our preservation technique has been found to preserve DOC, $\delta^{13} \mathrm{C}_{\mathrm{DOC}}$, and CDOM properties (own unpublished results).

\subsection{DOC analysis}

DOC and $\delta^{13} \mathrm{C}_{\mathrm{DOC}}$ were analyzed with an Aurora1030 total organic carbon analyzer (OI Analytical) coupled to a Delta $\mathrm{V}$ Advantage isotope ratio mass spectrometer (KU Leuven, Belgium). Typical precision observed in duplicate samples was in $>95 \%$ cases $< \pm 5 \%$ for DOC, and $\pm 0.2 \%$ for $\delta^{13} C_{\text {DOC }}$. Quantification and calibration was performed with series of standards prepared in different concentrations, using both IAEA-C6 $\left(\delta^{13} \mathrm{C}=-10.4 \%\right.$ ) and in-house sucrose standards $\left(\delta^{13} \mathrm{C}=-26.9 \%\right.$ ). All data are reported in the $\delta$ notation relative to VPDB (Vienna Pee Dee Belemnite).

\subsection{CDOM analysis and calculations}

Absorbance was recorded on a Perkin-Elmer UV/Vis 650S spectrophotometer (Université Libre de Bruxelles) using a $1 \mathrm{~cm}$ quartz cuvette. Absorbance spectra were measured between 190 and $900 \mathrm{~nm}$ at $1 \mathrm{~nm}$ increments, and instrument noise was assessed by using ultrapure (Type 1) Milli-Q (Millipore) water as blank. After subtracting the blank spectrum, the correction for scattering and index of refraction was performed by fitting the absorption spectra to the data over the
$200-700 \mathrm{~nm}$ range according to the following equation:

$A_{\lambda}=A_{0} \mathrm{e}^{-S\left(\lambda-\lambda_{0}\right)}+K$,

where $A_{\lambda}$ and $\mathrm{A}_{0}$ are the absorbance measured at defined wavelength $\lambda$ and at reference wavelength $\lambda_{0}=375 \mathrm{~nm}$, respectively, $S$ the spectral slope $\left(\mathrm{nm}^{-1}\right)$ that describes the approximate exponential decline in absorption with increasing wavelength and $K$ a background offset. The fit was not used for any purpose other than to provide an offset value $K$ that was then subtracted from the whole spectrum (Lambert et al., 2015).

The SUVA $_{254}$ was calculated as the UV absorbance at $\lambda=254 \mathrm{~nm}\left(A_{254}\right)$ normalized to the corresponding DOC concentration (Weishaar et al., 2003). The natural UV absorbance of $\mathrm{Fe}$ at $\lambda=254 \mathrm{~nm}$ was estimated based on measured $\mathrm{Fe}$ concentrations and was then subtracted from the UV absorbance measured. The corrected value of $A_{254}$ was then used to calculate $\mathrm{SUVA}_{254}$. The $\mathrm{SUVA}_{254}$ was used as an indicator of the aromaticity of DOC, with high values (> $3.5 \mathrm{~L} \mathrm{mgC}^{-1} \mathrm{~m}^{-1}$ ) indicative of the presence of more complex aromatic moieties and low values $\left(<3 \mathrm{~L} \mathrm{mgC}^{-1} \mathrm{~m}^{-1}\right)$ indicative of the presence of more aliphatic compounds (Weishaar et al., 2003).

Napierian absorption coefficients were calculated according to

$a_{\lambda}=2.303 \times A_{\lambda} / L$,

where $a_{\lambda}$ is the absorption coefficient $\left(\mathrm{m}^{-1}\right)$ at wavelength $\lambda, A_{\lambda}$ the absorbance corrected at wavelength $\lambda$ and $L$ the path length of the optical cell in meters $(0.01 \mathrm{~m})$. CDOM was reported as the absorption coefficient at $350 \mathrm{~nm}\left(a_{350}\right)$. Spectral slopes for the intervals $275-295$ and $350-400 \mathrm{~nm}$ were determined from the linear regression of the log-transformed $a$ spectra vs. wavelength. The slope ratio $S_{\mathrm{R}}$ was calculated as the ratio of $S_{275-295}$ to $S_{350-400}$ according to Helms et al. (2008). $S_{\mathrm{R}}$ is related to the molecular weight distribution of DOM, with values less than 1 indicative of enrichment in high-molecular-weight compounds and high values above 1 indicative of a high degree of low-molecular-weight compounds (Helms et al., 2008).

\subsection{FDOM analysis and PARAFAC modeling}

Fluorescence intensity was recorded on a Perkin-Elmer LS55 fluorescence spectrometer (Université Libre de Bruxelles) using a $1 \mathrm{~cm}$ quartz cuvette across excitation wavelengths of $220-450 \mathrm{~nm}(5 \mathrm{~nm}$ increments) and emission wavelengths of $230-600 \mathrm{~nm}(0.5 \mathrm{~nm}$ increments) in order to build excitationemission matrices (EEMs). If necessary, samples were diluted until $A_{254}<0.2 \mathrm{~m}^{-1}$ to avoid problematic inner filter effects (Ohno, 2002). Before each measurement session (i.e., each day), a Milli-Q water sample was also analyzed. EEM preprocessing, including removing first and second Raman scattering, standardization to Raman units, absorbance 
corrections and inner filter effects, was performed prior the PARAFAC modeling. The scans were standardized to Raman units (normalized to the integral of the Raman signal between 390 and $410 \mathrm{~nm}$ in emission at a fixed excitation of $350 \mathrm{~nm}$ ) with a Milli-Q water sample run the same day as the samples (Zepp et al., 2004). The PARAFAC model was built using MATLAB (MathWorks, Natick, MA, USA) and DOM Fluorescence Toolbox 1.7. Validation of the PARAFAC model was performed by split-half analysis and random initialization (Stedmon and Bro, 2008). Additional samples analyzed in the same manner and collected from (1) tributaries of the Zambezi and the Kafue rivers as well as during an almost 2-year monitoring period of the Zambezi and the Kafue rivers ( $n=42$; data not published) and (2) the Congo Basin $(n=164$; data not published) were added to the data set. This was done to increase the variability of DOM fluorescence signatures and therefore help detect components that could have been present in insufficient quantity to be detected in our environment (Stedmon and Markager, 2005). The maximum fluorescence $F_{\text {Max }}$ values of each component for a particular sample provided by the model were summed to calculate the total fluorescence signal $F_{\text {Tot }}$ of the sample in Raman's unit (RU). The relative abundance of any particular PARAFAC component $X$ was then calculated as $\% \mathrm{C}_{X}=F_{\mathrm{Max}}(X) / F_{\text {Tot }}$. The FI was calculated as the ratio of the emission intensities at 470 and $520 \mathrm{~nm}$ at an excitation wavelength of $370 \mathrm{~nm}$ (McKnight et al., 2001). A higher FI value (e.g., 1.8) indicates an aquatic microbial DOM source, while a lower value (e.g., 1.2) indicates a terrestrial source; intermediate values indicate a mixed DOM source.

\subsection{Statistical analysis}

A principal component analysis (PCA) was initially used as a diagnostic tool to examine relationships between PARARAC results, DOM concentration and composition assessed by optical proxies and isotopic measurements in order to better characterize the origin and source of the PARAFAC components identified in the study. The PCA was performed on scaled variables using the prcomp function in $\mathrm{R}$ software. DOC concentrations, stable carbon isotopic composition, optical indices $\left(\mathrm{SUVA}_{254}, S_{\mathrm{R}}, \mathrm{FI}\right), a_{350}, F_{\mathrm{Max}}$ and the relative abundance of PARAFAC components were used as the variables for the PCA. Given the different units of the variables used in the PCA, data were scaled to zero mean and unit variance as recommended (Borcard et al., 2011). The PCA was then performed on the correlation matrix of the scaled variables.
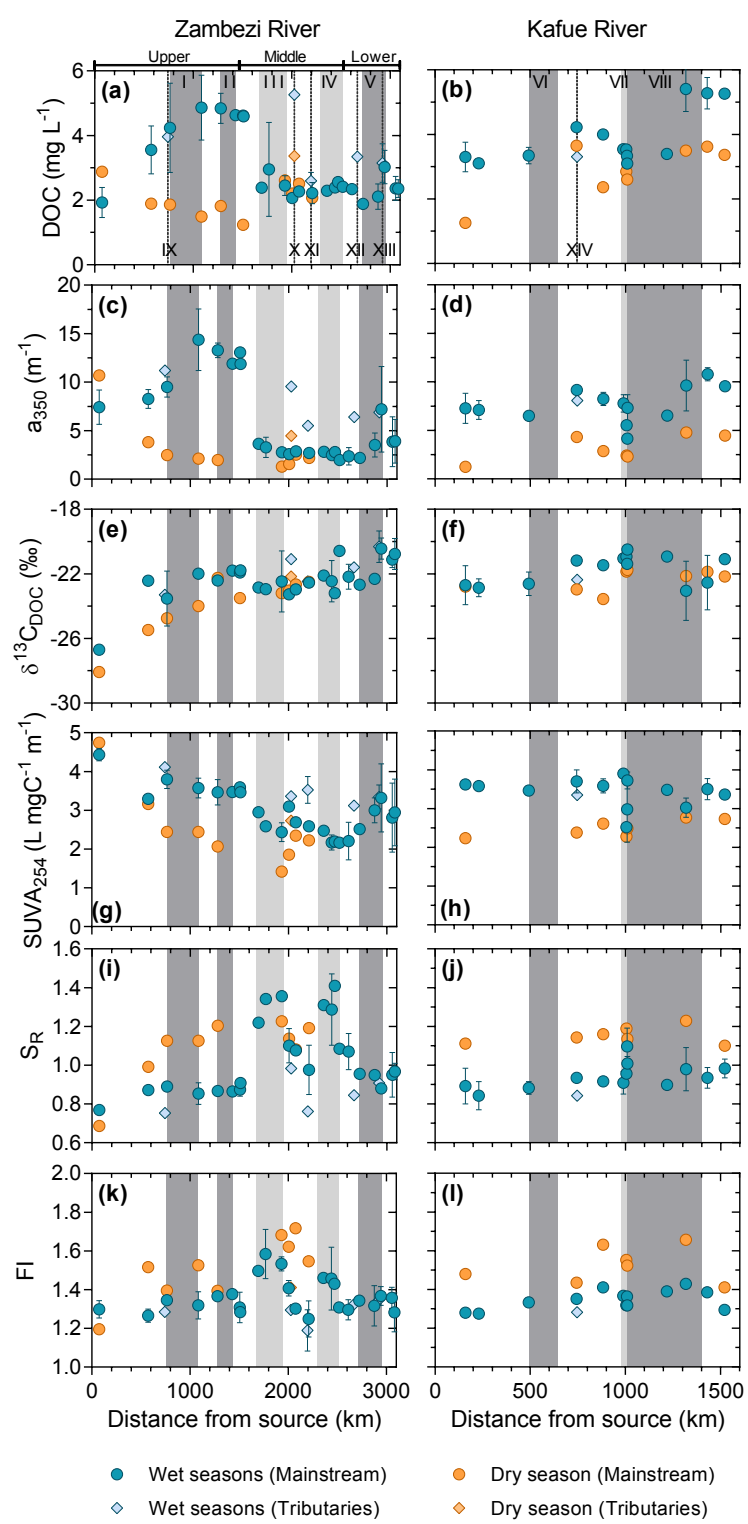

Figure 3. Longitudinal variations in DOM properties along the Zambezi River (left panels) and the Kafue River (right panels) during the wet and the dry seasons. From top to bottom, the panels represent DOC, $a_{350}, \delta^{13} \mathrm{C}_{\mathrm{DOC}}, \mathrm{SUVA}_{254}, S_{\mathrm{R}}$ and FI. Dark-gray and light-gray rectangles in the background represent the approximate position along the mainstream of wetlands/floodplains areas and reservoirs, respectively. Roman numerals refer to (I) Barotse Floodplain, (II) Chobe Swamps, (III) Kariba Reservoir, (IV) Cahora Bassa Reservoir, (V) lower Zambezi wetlands for the Zambezi River and (VI) Lukanga Swamps, (VII) Itezhi Tezhi Reservoir, and (VIII) Kafue Flats for the Kafue River. The diamonds represent samples collected from main tributaries upstream of their confluence with mainstreams: (IX) the Kabompo, (X) the Kafue, (XI) the Luangwa, (XII) the Mazoe and (XIII) Shire River for the Zambezi River, and (XIV) the Lunga River for the Kafue River. Symbols and error bars for data collected during the wet seasons represent the average and standard deviation between the two field campaigns performed in 2012 and 2013, respectively. 


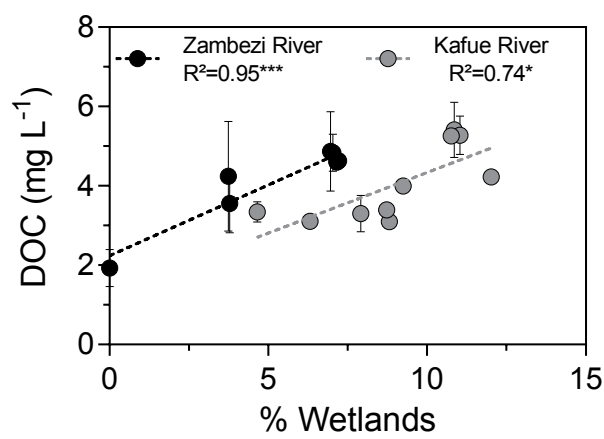

Figure 4. Relationships between DOC and \% wetlands in the catchment in the Zambezi and the Kafue rivers during the wet periods, with ${ }^{*} p<0.1$, and ${ }^{* * *} p<0.001$. For the Zambezi, only the samples collected in the upper part of the basin have been considered due to the effect of the Kariba and Cahora Bassa reservoirs on the longitudinal pattern of DOC concentrations.

\section{Results}

\subsection{Longitudinal patterns in DOC concentration, composition and DOM optical properties}

Data were acquired during two wet seasons and one dry season. The two wet season data sets are discussed together hereafter. DOC concentrations in the Zambezi River ranged from $1.9 \pm 0.1$ to $4.9 \pm 1.0 \mathrm{mg} \mathrm{L}^{-1}$ during the wet periods and from 1.2 to $2.9 \mathrm{mg} \mathrm{L}^{-1}$ during the dry period (Fig. 3a). Along the upper Zambezi, DOC increased downstream during the wet seasons, while DOC gradually decreased downstream during the dry season. In the Kariba Reservoir, DOC variability between wet and dry seasons was relatively low, and concentrations ranged from $2.4 \pm 0.3$ to $2.9 \pm 1.4 \mathrm{mg} \mathrm{L}^{-1}$. DOC exhibited relatively small variability downstream of the Kariba Reservoir and along the lower Zambezi, with the exception of a slight increase during the wet seasons downstream of the confluence with the Shire River (outlet of Lake Malawi). In the Kafue River, DOC was generally higher during the wet seasons (from $3.1 \pm 0.1$ to $5.4 \pm 0.7 \mathrm{mg} \mathrm{L}^{-1}$ ) compared to the dry season (from 1.3 to $3.6 \mathrm{mg} \mathrm{L}^{-1}$; Fig. 3b). Despite this seasonal difference, DOC increased gradually downstream during both wet and dry seasons. DOC concentrations in the Itezhi Tezhi Reservoir showed a decrease $(\sim 25 \%)$ during the wet seasons but an increase $(\sim 20 \%)$ during the dry season compared to the upstream station. During the wet periods, DOC concentrations in the upper Zambezi and the Kafue River were closely correlated with the extent of wetlands (Fig. 4).

The $a_{350}$ values (Fig. $3 \mathrm{c}$ and d), used to assess the level of $\mathrm{CDOM}$, were higher during the wet seasons (1.7 to $16.6 \mathrm{~m}^{-1}$ in the Zambezi and 3.9 to $11.5 \mathrm{~m}^{-1}$ in the Kafue) than during the dry season (1.3 to $10.7 \mathrm{~m}^{-1}$ in the Zambezi and 1.2 to $4.7 \mathrm{~m}^{-1}$ in the Kafue). They followed similar spatial and seasonal patterns as DOC concentrations, with some differ- ences. First, decreases in $a_{350}$ values were more pronounced than for DOC, especially in the upper Zambezi during the dry season and in the Kariba and Itezhi Tezhi reservoirs during the wet season. For example, while DOC decreased by a factor $\sim 2$ as the Zambezi enters the Kariba Reservoir during the wet periods, $a_{350}$ decreased by a factor $\sim 4$. Secondly, while DOC concentrations were higher at the outlet of reservoirs compared to upstream stations during the dry season, $a_{350}$ values were lower.

$\delta^{13} \mathrm{C}_{\mathrm{DOC}}$ values in the Zambezi Basin ranged from -28.1 to $-19.6 \%$ over the study period, i.e., from typical $\mathrm{C}_{3}$ dominated values $\left(\mathrm{C}_{3}\right.$ end-member was estimated at $-28.5 \%$ o according to Kohn (2010) to values representing mixed $\mathrm{C}_{3}$ $\mathrm{C}_{4}$ vegetation $\left(\delta^{13} \mathrm{C}\right.$ value for the $\mathrm{C}_{4}$ end-member $-12.1 \%$; Tamooh et al., 2012). $\delta^{13} \mathrm{C}_{\mathrm{DOC}}$ showed a gradual increase along the Zambezi River during all periods, from -28.1 and $-26.5 \%$ at the source to -21.4 to $-20.1 \%$ o near its delta, the latter being especially marked between the two first sampling sites in the upper Zambezi (Fig. 3e), while no significant pattern was observed along the Kafue River (values between -25.9 and $-20.5 \%$, Fig. 3f).

DOM at the source of the Zambezi exhibited the highest $\mathrm{SUVA}_{254}$ (> $4 \mathrm{~L} \mathrm{mgC}^{-1} \mathrm{~m}^{-1}$, indicating strong aromaticity), and lowest $S_{\mathrm{R}}(<0.8$, indicative of high molecular weight) values during both wet and dry seasons (Fig. $3 \mathrm{~g}$ and i). During the wet seasons, the upper Zambezi was characterized by stable $\mathrm{SUVA}_{254}\left(3.5-4.0 \mathrm{~L} \mathrm{mgC}^{-1} \mathrm{~m}^{-1}\right)$ and low $S_{\mathrm{R}}$ $(0.85-0.91)$ values. In the middle Zambezi, $\mathrm{SUVA}_{254}$ and $S_{\mathrm{R}}$ values were lowest $\left(2.2 \pm 0.2-2.9 \pm 0.1 \mathrm{~L} \mathrm{mgC}^{-1} \mathrm{~m}^{-1}\right)$ and highest $(1.22 \pm 0.09-1.41 \pm 0.01)$ in the Kariba and the Cahora Bassa reservoirs compared to samples collected inbetween $\left(2.6 \pm 0.1-3.1 \pm 0.02 \mathrm{~L} \mathrm{mgC}^{-1} \mathrm{~m}^{-1}\right.$ for $\mathrm{SUVA}_{254}$ and $0.97 \pm 0.1-1.10 \pm 0.08$ for $S_{\mathrm{R}}$ ). Overall, $\mathrm{SUVA}_{254}$ increased from $2.1 \pm 0.5$ to $2.9 \pm 0.9 \mathrm{~L} \mathrm{mgC}^{-1} \mathrm{~m}^{-1}$, whereas $S_{\mathrm{R}}$ decreased from $1.08 \pm 0.09$ to $0.97 \pm 0.04$ in the lower Zambezi, with maximum $\left(3.3 \pm 0.9 \mathrm{~L} \mathrm{mgC}^{-1} \mathrm{~m}^{-1}\right)$ and minimum $(0.88 \pm 0.006)$ values recorded below the confluence with the Shire River, respectively. During the wet periods, FI values ranged between 1.24 and 1.41 in the mainstream, and between 1.43 and 1.58 in reservoirs (Fig. 3k). FI values during the dry season were generally higher than during the wet periods with values ranging from 1.29 to 1.72 , except at the source of the Zambezi, where an FI value of 1.19 was observed.

In the Kafue River, variations in DOM composition were marked between the wet and dry seasons, but minimal along the longitudinal transect (Fig. $3 \mathrm{~h}, \mathrm{j}$ and 1 ). $\mathrm{SUVA}_{254}$ and $S_{\mathrm{R}}$ ranged from 3.5 to $4.0 \mathrm{~L} \mathrm{mgC}^{-1} \mathrm{~m}^{-1}$ and from 0.79 to 1.05 , respectively, during the wet seasons, except in the Itezhi Tezhi Reservoir, where SUVA 254 decreased to $2.4 \mathrm{~L} \mathrm{mgC}^{-1} \mathrm{~m}^{-1}$ and $S_{\mathrm{R}}$ increased up to 1.16 . Values were quite stable during dry periods, and ranged between 2.2 and $2.8 \mathrm{~L} \mathrm{mgC}^{-1} \mathrm{~m}^{-1}$ for $\mathrm{SUVA}_{254}$ and from 1.11 to 1.22 for $S_{\mathrm{R}}$. FI values ranged between 1.27 and 1.42 during the wet seasons, and between 1.41 and 1.74 during the dry season. 
Table 1. Spectral characteristics of the five fluorophores identified by PARAFAC modeling, correspondence with previously identified components in different environments, general assignment, and possible source. Numbers in brackets refer to the second peak of maximal excitation.

\begin{tabular}{|c|c|c|c|c|c|c|c|c|c|c|c|c|}
\hline \multirow[b]{2}{*}{ Component } & \multirow[b]{2}{*}{$\begin{array}{l}\text { Maximum } \\
\text { excitation (nm) }\end{array}$} & \multirow[b]{2}{*}{$\begin{array}{r}\text { Maximum } \\
\text { emission }(\mathrm{nm})\end{array}$} & \multicolumn{8}{|c|}{ Comparison with other environments } & \multirow[b]{2}{*}{$\begin{array}{l}\text { Assignment } \\
\text { source }^{\mathrm{a}}\end{array}$} & \multirow[b]{2}{*}{$\begin{array}{l}\text { Possible } \\
\text { source }\end{array}$} \\
\hline & & & $\begin{array}{r}\text { St Lawrence } \\
\text { River }^{1}\end{array}$ & $\begin{array}{r}\text { Large Arctic } \\
\text { rivers }^{2}\end{array}$ & $\begin{array}{r}\text { Boreal } \\
\text { lakes }^{3,4}\end{array}$ & $\begin{array}{l}\text { Subtropical } \\
\text { wetlands } s^{5,6}\end{array}$ & $\begin{array}{r}\text { Tropical } \\
\text { wetland }^{7}\end{array}$ & $\begin{array}{r}\text { Temperate } \\
\text { estuary }^{8}\end{array}$ & $\begin{array}{l}\text { Coastal } \\
\text { waters } 9\end{array}$ & $\begin{array}{r}\text { Marine } \\
\text { waters }^{10}\end{array}$ & & \\
\hline $\mathrm{C} 1$ & $<240(325)$ & 443 & $\mathrm{C} 2$ & $\mathrm{C} 1$ & $\mathrm{C} 4$ & $\mathrm{C} 1$ & $\mathrm{C} 1$ & $\mathrm{C} 4$ & - & $\mathrm{C} 1$ & Terrestrial humic-like & $\mathrm{T}$ \\
\hline $\mathrm{C} 2$ & $<240(365)$ & 517 & $\mathrm{C} 3$ & $\mathrm{C} 3$ & $\mathrm{C} 3$ & $\mathrm{C} 5$ & $\mathrm{C} 4$ & $\mathrm{C} 2$ & $\mathrm{C} 3$ & - & Terrestrial humic-like & $\mathrm{T}$ \\
\hline $\mathrm{C} 3$ & $<240(305)$ & 383 & $\mathrm{C} 7$ & - & $\mathrm{C} 2$ & $\mathrm{C} 4$ & $\mathrm{C} 3$ & C6 & $\mathrm{C} 6$ & $\mathrm{C} 4$ & Microbial humic-like & $\mathrm{Au}^{9}, \mathrm{M}^{3,7,10}, \mathrm{An}^{8}$ \\
\hline $\mathrm{C} 4$ & $<240$ & 405 & $\mathrm{C} 1$ & - & C5 & $\mathrm{C} 2$ & $\mathrm{C} 2$ & $\mathrm{C} 1$ & $\mathrm{C} 1$ & - & Terrestrial humic-like & $\mathrm{T}^{5,6,8}, \mathrm{P}^{1,4}$ \\
\hline $\mathrm{C} 5$ & $275(<240)$ & 337 & $\mathrm{C} 4$ & $\mathrm{C} 5$ & C6 & $\mathrm{C} 8$ & - & $\mathrm{C} 7$ & $\mathrm{C} 4$ & $\mathrm{C} 2$ & Tryptophan-like & $\mathrm{Au}^{1,9}, \mathrm{M}^{2,8}$ \\
\hline
\end{tabular}

\subsection{Longitudinal patterns in FDOM}

PARAFAC modeling identified three terrestrial humic-like components ( $\mathrm{C} 1, \mathrm{C} 2$ and $\mathrm{C} 4)$, one aquatic microbial humiclike component (C3) and one protein tryptophan-like (C5) component (Table 1 and Supplement Fig. S1). In the Zambezi River, the fluorescence intensities $\left(F_{\text {Max }}\right)$ of PARAFAC components during the wet seasons presented patterns similar to DOC concentrations with some exceptions (Fig. 5). $F_{\text {Max }}$ of the $\mathrm{C} 4$ component presented the higher percentage of increase compared to the other component in river sections flowing through wetlands/floodplains in the upper and lower Zambezi (data not shown). All terrestrial and microbial humic-like components showed a systematic and marked decrease in their $F_{\text {Max }}$ values in reservoirs, while $F_{\text {Max }}$ of C5 decreased in a smaller proportion in the Kariba Reservoir and increased in the Cahora Bassa Reservoir. During the dry season, $F_{\text {Max }}$ of terrestrial humic-like components decreased downstream concurrent with DOC concentrations, while $F_{\text {Max }}$ remained stable for $\mathrm{C} 3$ or increased for $\mathrm{C} 5$. In the Kafue River, $F_{\mathrm{Max}}$ of all components followed similar spatial and temporal patterns as those of DOC concentrations. The main difference observed was that while $F_{\text {Max }}$ values of humic-like compounds were lower during the dry season compared to the wet seasons, $F_{\text {Max }}$ of C5 exhibited similar values across the hydrological cycle.

As a direct consequence of the spatial and temporal differences in $F_{\text {Max }}$ of PARAFAC components, the relative contribution of each component to the total fluorescence signal $F_{\text {TOT }}$ showed distinct patterns (Fig. 6). Thus, the downstream decrease in $\% \mathrm{C} 1$ and $\% \mathrm{C} 2$ observed in the upper Zambezi during the wet seasons can be related to the parallel increase in $\% \mathrm{C} 4$, the latter being due to the more pronounced increase in $F_{\mathrm{Max}}$ of $\mathrm{C} 4$ relative to the other components. The same patterns for $\% \mathrm{C} 1$ and $\% \mathrm{C} 2$ observed during the dry season, however, reflect the fact that $F_{\text {Max }}$ values of $\mathrm{C} 3$ and $\mathrm{C} 5$ were stable or increased during the dry season, respectively, while $F_{\mathrm{Max}}$ of $\mathrm{C} 1$ and $\mathrm{C} 2$ decreased. \%C5 was higher during the dry season compared to the wet seasons, and reached highest values in reservoirs during the wet periods due to its specific spatial and temporal variations in $F_{\text {Max }}$ values. No longitudinal changes in the relative abundance of PARAFAC compo- nents were observed along the Kafue River. Similar to what was observed along the Zambezi River, the dry season was marked by a decrease in $\% \mathrm{C} 4$ and an increase in $\% \mathrm{C} 5$, while $\% \mathrm{C} 1, \% \mathrm{C} 2$ and $\% \mathrm{C} 3$ were equivalent to values recorded during the wet seasons.

\subsection{Principal component analysis (PCA)}

The first two components of the PCA explained $71.7 \%$ of the variance and regrouped the variables into three main clusters (Fig. 7). The first includes \% $1, \% \mathrm{C} 2$ and samples collected at or near the source of the Zambezi. The second group was defined by $\% \mathrm{C} 4$ and several variables including DOC, $F_{\mathrm{Max}}$, $\mathrm{SUVA}_{254}$ and $a_{350}$. Samples from the upper Zambezi and from the Kafue rivers (excluding reservoirs) were mainly located in this cluster. Finally, \%C3 and \%C5 were clustered with $S_{\mathrm{R}}$ and FI. Samples from reservoirs (including Kariba, Cahora Bassa and Itezhi Tezhi) were almost all in this cluster. Samples collected in the middle and lower Zambezi during both the wet and dry seasons were located between the distinct clusters defined by PARAFAC components and DOM concentration and composition.

\section{Discussion}

\subsection{Identification of PARAFAC components}

Humic-like components $\mathrm{C} 1$ and $\mathrm{C} 2$ are among the most common fluorophores found in freshwaters and are associated with high-molecular-weight and aromatic compounds of terrestrial origin (Stedmon and Markager, 2005; Yamashita et al., 2008; Walker et al., 2013). Component C4 has been reported to be of terrestrial origin (Stedmon and Markager, 2005; Kothawala et al., 2015) or to be a photoproduct of terrestrially derived DOM (Massicotte and Frenette, 2011). The association of \%C4 with DOC concentrations and terrestrial optical indices including $a_{350}$ and $\mathrm{SUVA}_{254}$ advocates for a terrestrial origin of this component (Fig. 7). Conversely, \%C3 and \% $\% 5$ were negatively correlated with $a_{350}$ and $\mathrm{SUVA}_{254}$. C 3 and $\mathrm{C} 5$ components are respectively classified as microbial humic-like and tryptophan-like components related to the production of DOM within aquatic ecosystems 

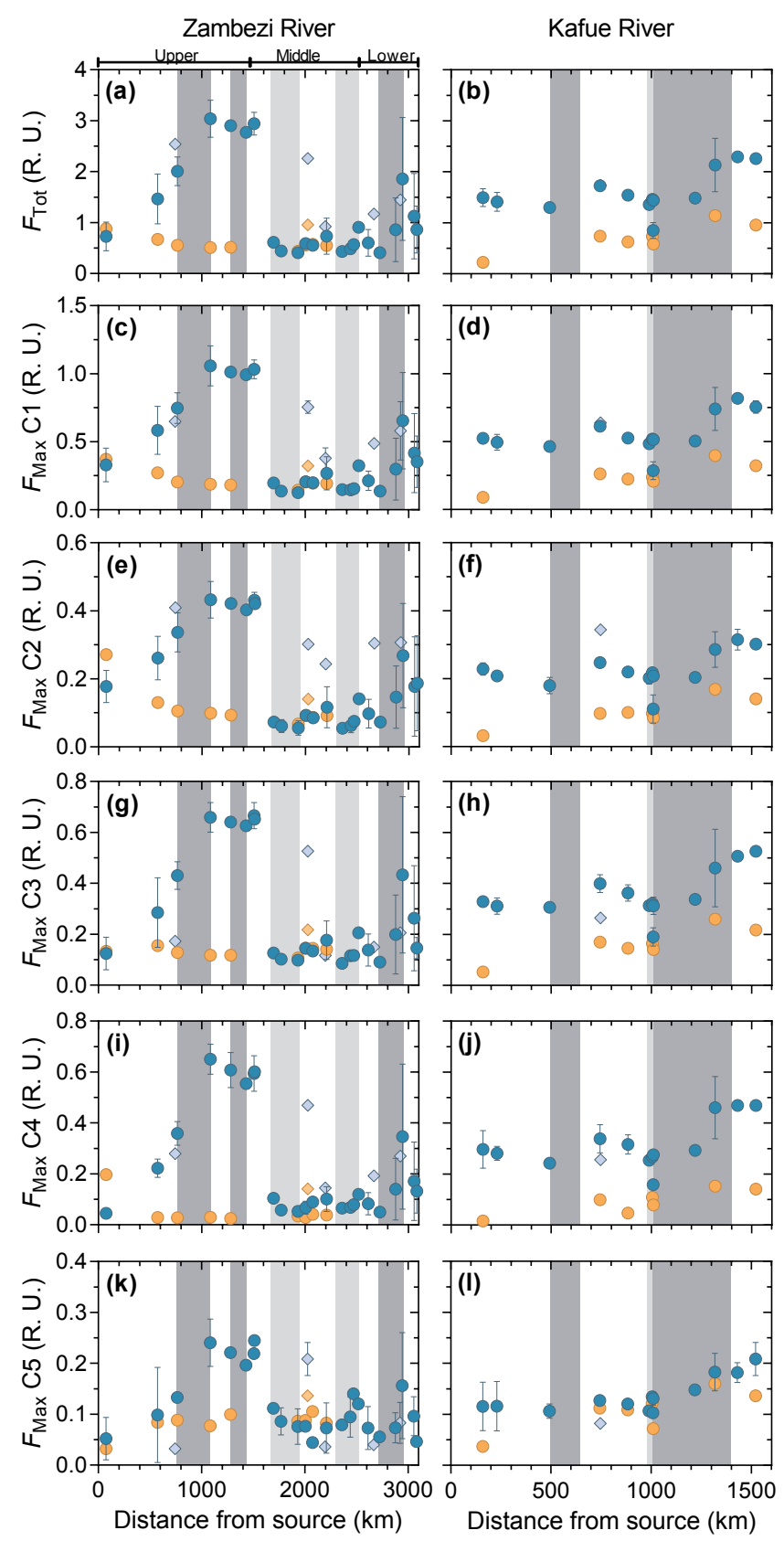

- Wet seasons (Mainstream)

- Dry season (Mainstream)

$\diamond$ Wet seasons (Tributaries)

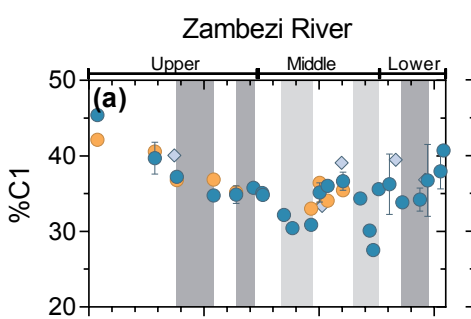

Kafue River
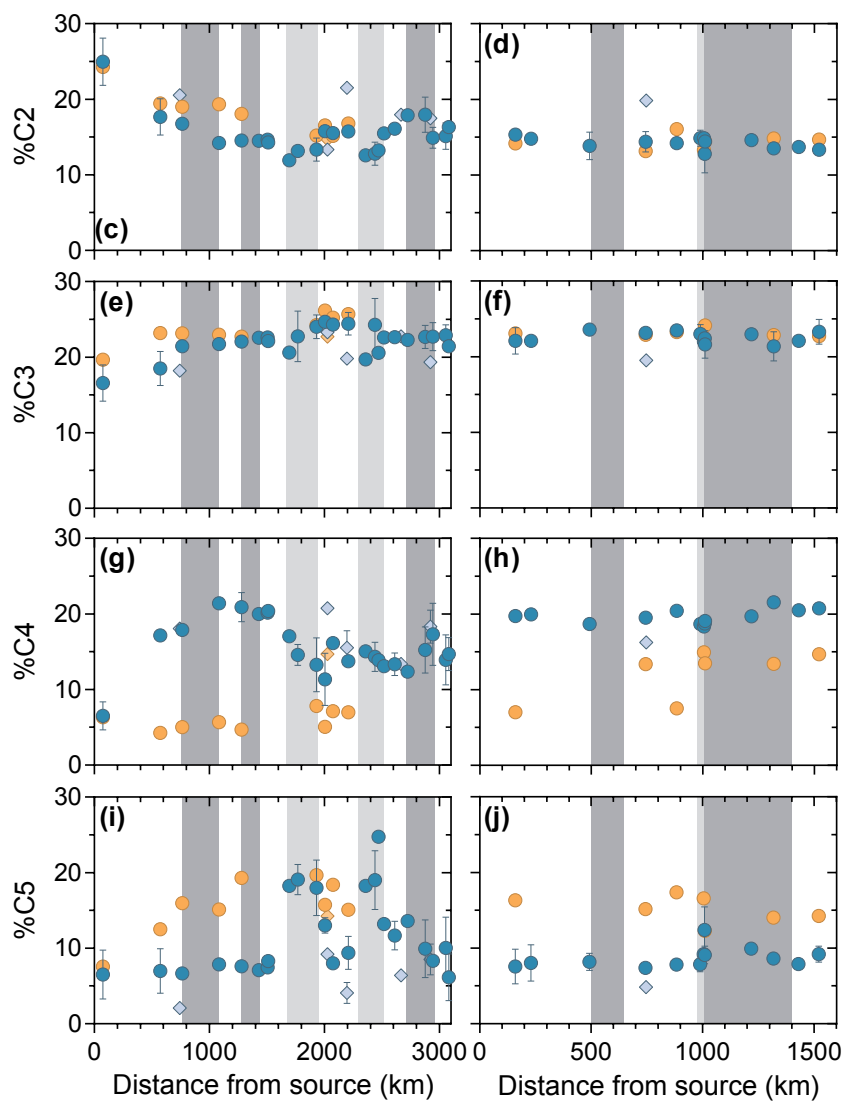

- Wet seasons (Mainstream)

- Dry season (Mainstream)

$\diamond \quad$ Wet seasons (Tributaries)

$\diamond \quad$ Dry season (Tributaries)

Figure 6. Longitudinal variations in the relative contribution of PARAFAC component along the Zambezi River (left panels) and the Kafue River (right panels) during the wet and the dry seasons. The diamonds represent samples taken from main tributaries upstream of their confluence with mainstreams.

ter column as previously reported in a wide variety of environments as marine (Jørgensen et al., 2011) and lake waters (Kellerman et al., 2015) for C3 and large Arctic rivers (Walker et al., 2013) or small temperate catchments (Stedmon and Markager, 2005) for C5. The opposite relationship of $\% \mathrm{C} 1$ and $\% \mathrm{C} 2$ vs. \% 3 (Fig. 7) suggests that $\mathrm{C} 3$ would be the result of the transformation of terrestrial components $\mathrm{C} 1$ and $\mathrm{C} 2$ through biological activity in the water column as suggested by Jørgensen et al. (2011). The distribution of samples along PC1 is thus likely controlled by the transition from terrestrial DOM with a high degree of aromaticity 


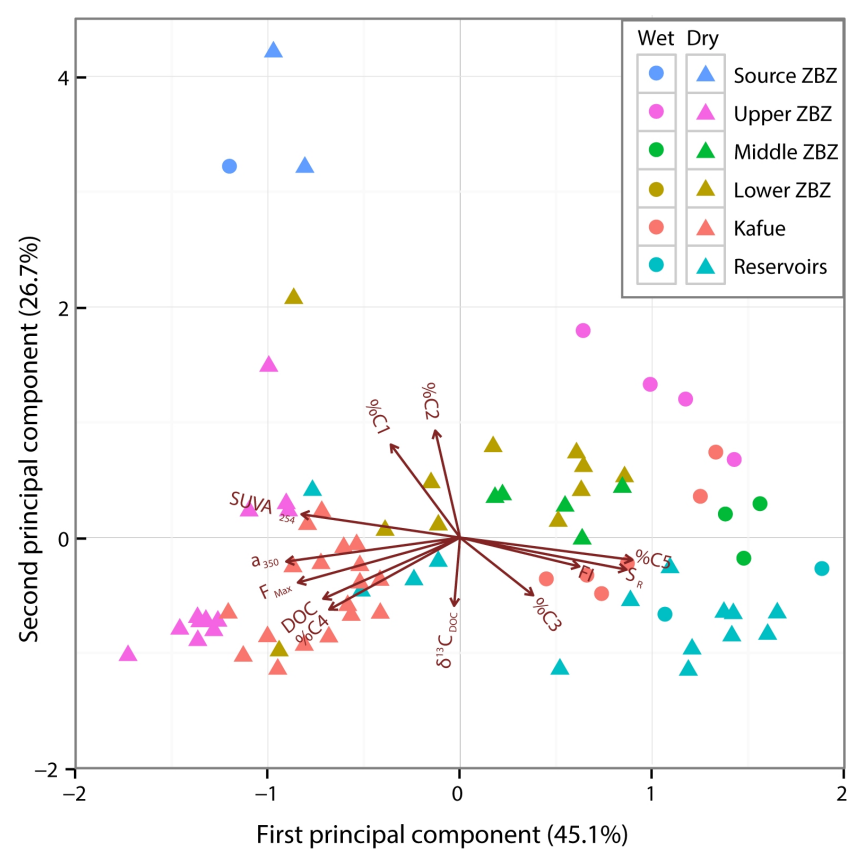

Figure 7. Graphical representation of PCA results, including loadings plot for the input variables and scores plot for water samples collected during the wet (circles) and dry (triangles) seasons. Water samples from the Zambezi River (ZBZ) were classified according to its source and the three major segments of the Zambezi Basin. Samples from reservoirs (i.e., Kariba, Cahora Bassa and Itezhi Tezhi reservoirs) were classified together.

and humic content (negative loadings) to less aromatic DOM produced within the aquatic ecosystem by the degradation of terrestrial DOM during transport and/or by autochthonous sources (positive loadings). Regarding PC2, \% 1 and $\% \mathrm{C} 2$ were also in strong contrast to $\delta^{13} \mathrm{C}_{\mathrm{DOC}}$. Considering the highest level of \% 1 and $\% \mathrm{C} 2$ at the source of the Zambezi and suggesting that $\delta^{13} \mathrm{C}_{\mathrm{DOC}}$ was primarily controlled by the vegetation gradient along the mainstem from $\mathrm{C}_{3}$ forest toward mixed $\mathrm{C}_{3}-\mathrm{C}_{4}$ savannah, this suggests that land cover influences DOM in the river network.

\subsection{Relative contribution of $\mathrm{C}_{3}$ and $\mathrm{C}_{4}$ plants to the DOM pool}

The $\delta^{13} \mathrm{C}_{\mathrm{DOC}}$ values in the Zambezi Basin were in the range of data reported for other African river systems, being higher than those measured in $\mathrm{C}_{3}$ tropical rainforest catchments such as the Congo (Spencer et al., 2009; Bouillon et al., 2014), the Ogooué (Lambert et al., 2015) or the Nyong rivers (Brunet et al., 2009), but similar to catchments with significant areas of $\mathrm{C}_{4}$ vegetation (e.g., savannah) such as the Tana (Tamooh et al., 2012), the Niger (Lambert et al., 2015) or the Betsiboka and Rianilia rivers (Marwick et al., 2014).

The increase in $\delta^{13} \mathrm{C}_{\mathrm{DOC}}$ in the Zambezi, especially marked along the first stations, was consistent with the veg- etation gradient along the mainstem, where upstream $\mathrm{C}_{3}$ forest ecosystems quickly shift towards mixed $\mathrm{C}_{3}-\mathrm{C}_{4}$ grassland and woodland/shrubland ecosystems that dominate in the basin (Fig. S2). $\delta^{13} \mathrm{C}_{\mathrm{DOC}}$ did not show marked depletion in surface waters of reservoirs, suggesting that phytoplankton production had little net effect on $\delta^{13} \mathrm{C}_{\mathrm{DOC}}$ (Bouillon et al., 2009; Tamooh et al., 2012). In addition to an increased contribution from $\mathrm{C}_{4}$ vegetation, the downstream increase in $\delta^{13} \mathrm{C}_{\mathrm{DOC}}$ could also partially result from differences in the $\delta^{13} \mathrm{C}$ composition of $\mathrm{C}_{3}$ vegetation at the basin scale. Indeed, $\delta^{13} \mathrm{C}$ values of $\mathrm{C}_{3}$ plants increase with decreasing mean annual precipitation (MAP; Kohn, 2010) and MAP in the Zambezi strongly varies from $>2000 \mathrm{~mm} \mathrm{yr}^{-1}$ in the northern part of the basin to $<500 \mathrm{~mm} \mathrm{yr}^{-1}$ in the southern part (Chenje, 2000). Using high-resolution maps of MAP (Hijmans et al., 2005); a digital elevation model at 3 arcsec resolution computed by the HydroSHEDS mapping product (http://hydrosheds.cr.usgs.gov/index.php); and the proposed equation of Kohn (2010) that estimates the $\delta^{13} \mathrm{C}$ signature of $\mathrm{C}_{3}$ vegetation based on MAP, altitude and latitude, we estimated an average value of $-27.1 \%$ and a range of variation from -29.3 to $-26.0 \%$ ofor the $\mathrm{C}_{3}$ vegetation of the Zambezi Basin (Fig. S3). This shift of $3.3 \%$ is smaller than the observed shift of $\sim 8 \%$ in the Zambezi River, indicating that the increase in $\delta^{13} \mathrm{C}_{\mathrm{DOC}}$ is to a large extent due to increased contribution from $\mathrm{C}_{4}$ vegetation. As a first approximation and using values of $-27.1 \%$ for $\mathrm{C}_{3}$ plants (calculated above) and $-12.1 \%$ or $\mathrm{C}_{4}$ plants (Tamooh et al., 2012), we found that DOM in the Zambezi Basin was mainly from $\mathrm{C}_{3}$ origin, with a relative contribution of $\sim 69$ and $\sim 75 \%$ for DOC during the wet and dry period, respectively.

\subsection{Seasonal and spatial variability in downstream gradients in DOM concentration and composition}

Altogether, data showed clear changes in the downstream gradients of DOM concentration and composition, both seasonally and spatially. In addition to the vegetation gradient, these changes were essentially controlled by three main factors: WRT and connectivity with wetlands/floodplains, both highly dependent on seasonal variations in water level (and discharge), and water retention by lakes/reservoirs that is more independent of seasonal variations in water level.

\subsubsection{Land cover and hydrological connectivity with wetlands/floodplains}

The DOM at the source of the Zambezi was clearly distinct from the rest of the basin, independent of the hydrological period (Fig. 6), with a strong aromatic character (highest $\mathrm{SUVA}_{254}$ ), a high degree of molecules with elevated molecular weight (lowest $S_{\mathrm{R}}$ ) and low $\delta^{13} \mathrm{C}_{\mathrm{DOC}}$. The shift in land cover (see Fig. S2) was reflected in the DOM gradient from the source station of the Zambezi to the next sampling site, and marked by an increase in $S_{\mathrm{R}}, \delta^{13} \mathrm{C}_{\mathrm{DOC}}$ and a decrease 
in $\mathrm{SUVA}_{254}$. This pattern is consistent with the role of forest in releasing more aromatic DOM of high molecular weight than other vegetation types in tropical freshwaters (Lambert et al., 2015).

Downstream, the variability in the optical properties of DOM between wet and dry seasons indicated seasonal changes in the sources of riverine DOM in relation with changes in water level and connectivity with wetlands/floodplains. The high $\mathrm{SUVA}_{254}$ and low $S_{\mathrm{R}}$ values during the wet seasons indicate the mobilization of fresh aromatic DOM of high molecular weight due to the increased water flow through DOM-rich upper soil horizons during high-flow periods (Striegl et al., 2005; Neff et al., 2006; Mann et al., 2012; Bouillon et al., 2014). Wetlands and floodplains were the main sources of terrestrial DOM at the basin scale during wet seasons, as shown by the relationships between DOC and wetland extent (Fig. 4). Among the different terrestrial humic-like components, $\mathrm{C} 4$ was the most affected by fluctuations in the connectivity with wetlands/floodplains. The increase in the relative contribution of $\mathrm{C} 4$ suggests that this component was mobilized in greater proportion relative to others (Fig. 6). This observation is consistent with a recent study conducted in boreal streams, in which a component similar to $\mathrm{C} 4$ was found to increase relative to other humic-like fluorophores (equivalent to $\mathrm{C} 1$ and $\mathrm{C} 2$ ) in stream waters during the peak spring melt due to the higher abundance of this component in uppermost soil horizons of wetlands (Kothawala et al., 2015). The longitudinal and seasonal variations in \% 4 in the upper Zambezi are consistent with the hypothesis that $\mathrm{C} 4$ is mainly produced in the upper soil horizons of wetlands/floodplains and therefore preferentially mobilized during high-flow periods.

\subsubsection{WRT modulates the downstream patterns of DOM}

During the dry season, DOM was characterized by lower SUVA $_{254}$ and higher $S_{\mathrm{R}}$ values, indicating the transport of compounds of lower aromaticity and lower average molecular weight compared to high-flow periods. The difference in downstream gradients of DOM compared to the wet seasons can be explained in part by the loss of connectivity between rivers and riparian wetlands/floodplains and the deepening of hydrological flow paths through DOM-poor deeper subsoil horizons during the dry season (e.g., Striegl et al., 2005; Bouillon et al., 2014). Changes in connectivity with wetland during the dry season were also found to strongly impact $\mathrm{CO}_{2}$ and $\mathrm{CH}_{4}$ distribution in the Zambezi (Teodoru et al., 2015). That being said, the considerable decrease in water discharge during dry/base-flow period compared to wet/highflow periods (Fig. 2) likely leads to a decrease in water velocities and subsequently to an increase in water residence time, allowing a more efficient degradation of terrestrial DOM along a given section. For illustration, the preferential downstream loss of $a_{350}$ compared to DOC in the upper Zambezi,

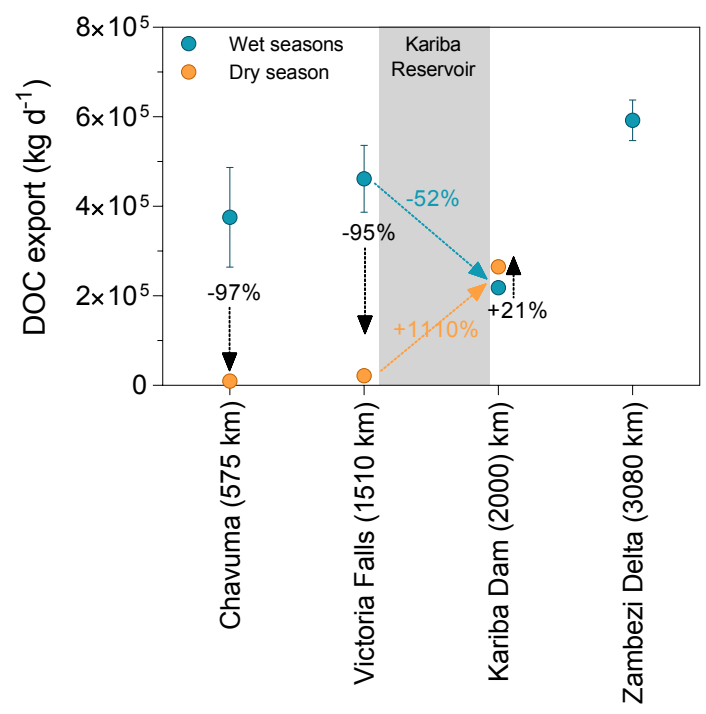

Figure 8. DOC exports calculated at different locations along the Zambezi River during the wet and the dry seasons. Vertical arrows represent changes in DOC exports at the same location between wet and dry seasons. Diagonal changes represent longitudinal variations.

associated with a gradual decrease in $\mathrm{SUVA}_{254}$ and increase in $S_{\mathrm{R}}$, is strong evidence of the preferential loss of the terrestrial and aromatic fraction of DOM through photodegradation (e.g., Spencer et al., 2009; Weyhenmeyer et al., 2012). The stable level of $F_{\text {Max }}$ of $\mathrm{C} 3$ suggests a continuous supply of this component, likely due to microbial degradation of terrestrial DOM. In addition, the increase in WRT could favor the accumulation of DOM from autochthonous sources as suggested by higher values of FI and the gradual increase in $F_{\text {Max }}$ for C5 (Figs. 3 and 4). Flushing during high-flow periods perturbs the downstream gradient of DOM established during base flow because (1) increasing water level mobilizes a greater proportion of terrestrial DOM and (2) higher water velocities increases the travel distance of humic and aromatic terrestrial compounds before removal due to microbial and photochemical degradation processes and limits the accumulation of autochthonous DOM in the water column.

\subsubsection{Retention of water by lakes/reservoirs}

Longitudinal patterns of DOM were affected by the presence of reservoirs where DOM was characterized by low aromaticity and molecular weight and higher microbial contribution independent of water level fluctuations (Figs. 5 and 7). The net loss of DOC and the preferential loss of the colored and aromatic fraction of DOM (based on $a_{350}$ and $\mathrm{SUVA}_{254}$, Fig. 3) in lakes and reservoirs have been previously documented (Hanson et al., 2011; Köhler et al., 2013) and attributed to the combination of several processes including flocculation, photochemical and microbial degradation (Cory et al., 2007; von Wachenfeldt and Tranvik, 2008; Köhler et 
Table 2. Temporal variations in DOM properties measured at the outlet of the Kariba Reservoir during an almost 2-year monthly sampling (from February 2012 to November 2013).

\begin{tabular}{|c|c|c|c|c|c|c|c|c|c|c|}
\hline & $\begin{array}{r}\text { DOC } \\
\left(\mathrm{mg} \mathrm{L}^{-1}\right)\end{array}$ & $\begin{array}{r}\delta^{13} \mathrm{C}_{\mathrm{DOC}} \\
(\% \circ)\end{array}$ & $\begin{array}{r}a_{350} \\
\left(\mathrm{~m}^{-1}\right)\end{array}$ & $\begin{array}{r}\mathrm{SUVA}_{254} \\
\left(\mathrm{~L} \mathrm{mgC}^{-1} \mathrm{~m}^{-1}\right)\end{array}$ & $S_{\mathrm{R}}$ & $\% \mathrm{C} 1$ & $\% \mathrm{C} 2$ & $\% \mathrm{C} 3$ & $\% \mathrm{C} 4$ & $\% \mathrm{C} 5$ \\
\hline Min & 2.00 & -23.96 & 1.00 & 1.39 & 1.010 & 27.7 & 12.2 & 16.1 & 4.0 & 12.3 \\
\hline Max & 2.60 & -22.26 & 2.50 & 3.11 & 1.428 & 36.5 & 16.6 & 26.2 & 13.8 & 35.9 \\
\hline Mean & 2.22 & -23.08 & 1.60 & 2.02 & 1.185 & 34.1 & 15.2 & 24.1 & 9.3 & 17.3 \\
\hline SD & 0.17 & 0.37 & 0.44 & 0.43 & 0.141 & 2.4 & 1.2 & 2.7 & 3.1 & 6.2 \\
\hline$n$ & 20 & 20 & 12 & 12 & 12 & 12 & 12 & 12 & 12 & 12 \\
\hline
\end{tabular}

al., 2013; Kothawala et al., 2014). Although we were not able to estimate the relative contribution of these mechanisms, our results indicate that the humic-like fractions of DOM (C1C4) were more susceptible to degradation compared to the protein-like fraction (C5), an observation consistent with recent studies carried out in boreal lakes (Kothawala et al., 2014). The level of fluorescence of C5 could be additionally sustained by the FDOM from primary producers such as macrophytes (Lapierre and Frenette, 2009) or phytoplankton (Yamashita et al., 2008), which also leads to low values of the partial pressure of $\mathrm{CO}_{2}$ below atmospheric equilibrium in the Kariba and Cahora Bassa reservoirs, while rivers (i.e., excluding reservoirs) displayed $\mathrm{CO}_{2}$ supersaturated conditions with respect to atmospheric equilibrium (Teodoru et al., 2015).

In agreement with others studies (e.g., Hanson et al., 2011), the effects of reservoirs on the fate of DOM were related to their specific WRT. The Itezhi Tezhi Reservoir had little effect on longitudinal patterns of DOM, as also suggested by a recent study (Zürbrugg et al., 2013), likely due to its relatively low WRT (0.7 years; Kunz et al., 2011) compared to the Kariba (5.7 years; Magadza, 2010) and the Cahora Bassa ( $\sim 2$ years; Davies et al., 2000) reservoirs. The DOC concentrations upstream and downstream of the Cahora Bassa Reservoir were similar but DOM composition exhibited significant changes within the reservoir compared to upstream and downstream stations, suggesting a balance between loss and production of new compounds. In fact, the Kariba Reservoir was the most important reservoir responsible for the perturbation of the longitudinal DOM gradient. The seasonal variability of DOM at the outlet of the Kariba Reservoir, in terms of both concentration and composition, was drastically reduced compared to the seasonal patterns observed in the upper Zambezi (Figs. 3 and 5). This was also illustrated by data from an almost 2-year monitoring of the Zambezi River $70 \mathrm{~km}$ downstream of the Kariba Dam, showing that the terrestrial fraction of DOM leaving the reservoir has undergone extensive transformation (Table 2). The role of lakes/reservoirs in lowering the seasonality of DOC in river network has also been evidenced in temperate and boreal streams and rivers in Sweden (Winterdahl et al., 2014).
Beyond their role as hotspots for DOM processing and mineralization, lakes/reservoirs act as a hydrological buffer and reduce the temporal variability of downstream water flow (Goodman et al., 2011; Lottig et al., 2013). Except for some isolated events, water discharge remained constant at Kariba Dam due to hydropower management (Fig. 2). Combined with the low temporal variability in DOM content (Table 2), DOC fluxes at the outlet of the Kariba Reservoir were relatively invariant and ranged between $8.3 \times 10^{7}$ and $9.7 \times 10^{7} \mathrm{~kg} \mathrm{yr}^{-1}$. This results in a 2-fold decrease in DOC fluxes during the wet seasons between upstream inputs from the upper Zambezi and export at the outlet of the Kariba Reservoir, but in an increase by a factor of 12 during the dry season (Fig. 8). From a longitudinal perspective, lakes/reservoirs can thus shift from DOM sources to sinks relative to upstream ecosystems while reducing the temporal variation of DOM fluxes and composition to downstream ecosystems. That being said, DOM losses were largely offset during the wet seasons by inputs from the Kafue and the Shire rivers as well as from wetlands in the lower Zambezi (Figs. 3 and 8). Therefore, the spatial arrangement of the different elements that constitute large river networks such as lakes/reservoirs, wetlands/floodplains and large tributaries is a key aspect in controlling DOM export at the basin scale.

\subsection{Comparison with others rivers}

The results of this study are similar to those reported in large rivers from other biomes regarding (1) the role of peak flow periods in exporting a greater portion of terrestrial aromatic and humic DOM (Neff et al., 2006; Duan et al., 2007; Holmes et al., 2008; Walker et al., 2013; Bouillon et al., 2014), (2) the disproportionate importance of riparian wetlands and floodplains in regulating in-stream chemistry (Fiebig et al. 1990; Dosskey and Bertsch, 1994; Hinton et al., 1998; Battin, 1998; Hanley et al., 2013; Abril et al., 2014; Borges et al., 2015b) and (3) the reactivity of terrestrial DOM during its transport (Massicotte and Frenette, 2011; Cawley et al., 2012; Wehenmeyer et al., 2012). However, while changes in temperature have been suggested as a secondary factor impacting DOM patterns in temperate and boreal streams and rivers (Kothawala et al., 2014; Winterdahl et al., 2014; Raymond et al., 2015), changes in longitudinal 
DOM patterns in the Zambezi Basin were only controlled by changes in hydrology. Indeed, water temperatures were systematically elevated with values mainly ranging from 25 to $29^{\circ} \mathrm{C}$ (data not shown) and no significant patterns were apparent between the contrasting seasons.

Our study clearly illustrates that the DOC in a given station is the legacy of upstream sources and their degree of processing during transport, and suggests that WRT is a major driver controlling the fate of DOM in freshwaters (the latter resulting from the competition between transport and degradation processes). Seasonal changes in DOM concentration and composition in large rivers assessed by monitoring programs are often explained by vertical changes in DOM sources mobilized during high-flow and base-flow conditions, i.e., shallow vs. deep sources along the soil profile (Neff et al., 2006; Mann et al., 2012; Bouillon et al., 2014). Our results show that the upstream degradation history of DOM during transit should also be taken into consideration, especially during base-flow periods. Given the strong reactivity of fresh terrestrial humic DOM exported during high-flow periods (e.g., Holmes et al., 2008; Mann et al., 2012) and the ability of large hydrological events to transport DOM downstream over large distances (Raymond et al., 2015), the functioning of large rivers at the seasonal scale and their impacts on receiving ecosystems (e.g., coastal waters) should deserve more attention.

\section{Data availability}

The digital elevation model HydroSHEDS (Lehner et al., 2008) is available at http://hydrosheds.cr.usgs.gov/index. php. Climatic data (including mean annual precipitation, Hijmans et al., 2005) are available at http://www.worldclim.org/. The Global Lakes and Wetlands database (Lehner and Döll, 2004) is available at http://www.worldwildlife.org/pages/ global-lakes-and-wetlands-database.

\section{The Supplement related to this article is available online at doi:10.5194/bg-13-2727-2016-supplement.}

Author contributions. The research project was designed by Alberto V. Borges and Steven Bouillon. Field data collection was done by Cristian R. Teodoru and Frank C. Nyoni. CDOM and FDOM measurements were done by Thibault Lambert with the help of François Darchambeau. Data analysis was done by Thibault Lambert with the help of Philippe Massicotte for PARAFAC modeling. The manuscript was drafted by Thibault Lambert and was commented, amended and approved by all co-authors.

Acknowledgements. This work was funded by the European Research Council (ERC-StG 240002 AFRIVAL), the Fonds National de la Recherche Scientifique (FNRS, FluoDOM J.0009.15), and the Research Foundation Flanders (FWO-Vlaanderen, travel grants to CRT). We thank Christiane Lancelot (Université Libre de Bruxelles) for access to the Perkin-Elmer UV/Vis 650S and two anonymous reviewers for constructive comments on the previous version of the manuscript. Thibault Lambert is a postdoctoral researcher at the FNRS. Alberto V. Borges is a senior research associate at the FNRS.

Edited by: M. Sarin

\section{References}

Abril, G., Martinez. J. M., Artigas, L. F., Moreira-Turcq. P., Benedetti, M. F., Vidal, L., Meziane, T., Kin, J. H., Bernardes, M. C., Savoye, N., Deborde, J., Souza, E. L., Albéric, P., Landim de Souza, M. F., and Roland, F.: Amazon River carbon dioxide outgassing fuelled by wetlands, Nature, 505, 395-398, doi:10.1038/nature12797, 2014.

Amon, R. M. W. and Benner, R.: Bacterial utilization of different size classes of dissolved organic matter, Limnol. Oceanogr., 41, 41-51, 1996.

Battin, T. J.: Dissolved organic matter and its optical properties in a blackwater tributary of the upper Oricono river, Venezuela, Org. Geochem., 28, 561-569, 1998.

Borcard, D., Gillet, F., and Legendre, P.: Numerical ecology with R, Springer New York, New York, 306 pp., doi:10.1007/978-14419-7976-6, 2011.

Borges, A. V., Darchambeau, F., Teodoru, C. R., Marwick, T. R., Tamooh, F., Geeraert, N., Omengo, F. O., Guerin, F., Lambert, T., Morana, C., Okuku, E., and Bouillon, S.: Globally significant greenhouse-gas emissions from african inland waters, Nat. Geosci., 8, 637-642, doi:10.1038/ngeo2486, 2015a.

Borges, A. V., Abril, G., Darchambeau, F., Teodoru, C. R., Deborde, J., Vidal, L. O., Lambert, T., and Bouillon, S.: Divergent biophysical controls of aquatic $\mathrm{CO}_{2}$ and $\mathrm{CH}_{4}$ in the World's two largest rivers, Sci. Rep., 5, 15614, doi:10.1038/srep15614, 2015b.

Bouillon, S., Abril, G., Borges, A. V., Dehairs, F., Govers, G., Hughes, H. J., Merckx, R., Meysman, F. J. R., Nyunja, J., Osburn, C., and Middelburg, J. J.: Distribution, origin and cycling of carbon in the Tana River (Kenya): a dry season basin-scale survey from headwaters to the delta, Biogeosciences, 6, 2475-2493, doi:10.5194/bg-6-2475-2009, 2009.

Bouillon, S., Yambélé, A., Gillikin, D. P., Teodoru, C. R., Darchambeau, F., Lambert, T., and Borges, A. V.: Contrasting biogeochemical characteristics of the Oubangui River and tributaries (Congo River basin), Sci. Rep., 4, 1-10, doi:10.1038/srep05402, 2014.

Brunet, F., Dubois, K., Veizer, J., Nkoue Ndondo, G. R., Ndam Ngoupayou, J. R., Boeglin, J. L., and Probst, J. L.: Terrestrial and fluvial carbon fluxes in a tropical watershed: Nyong basin, Cameroon, Chem. Geol., 265, 563-572, 2009.

Cawley, K. M., Wolski, P., Mladenov, N., and Jaffé, R.: Dissolved organic matter biogeochemistry along a transect of the Okavango delta, Bostwana, Wetlands, 32, 475-486, doi:10.1007/s13157012-0281-0, 2012.

Chenje, M.: State of the Environment Zambezi Basin 2000, SADC, IUCN, ZRA, and SARDC, Maseru, Lusaka and Harare, 334 pp., ISBN 978-1-77910-009-2, 2000. 
Cole, J. J., Prairie, Y. T., Caraco, N. F., McDowell, W. H., Tranvik, L. J., Striegl, R. G., Duarte, C. M., Kortelainen, P., Downing, J. A., Middelburg, J. J., and Melack, J.: Plumbing the global carbon cycle: integrating inland waters into the terrestrial carbon budget, Ecosystems, 10, 171-184, 2007.

Cory, R. M., McKnight, D. M., Chin, Y. P., Miller, P., and Jaros, C. L.: Chemical characteristics of fulvic acids from Arctic surface waters: Microbial contributions and photochemical transformations, J. Geophys. Res.-Biogeo., 112, G04S51, doi:10.1029/2006JG000343, 2007.

Davies, B. R., Beilfuss, R. D., and Thoms, M. C.: Cahora Bassa retrospective, 1974-1997: effects of flow regulation on the lower Zambezi River, Verh. Int. Ver. Theor. Angew., 20, 2149-2157, 2000.

del Giorgio, P. A. and Pace, M. L.: Relative independence of dissolved organic carbon transport and processing in a large temperate river: the Hudson River as both pipe and reactor, Limnol. Oceanogr., 53, 185-197, 2008.

Dosskey, M. G. and Bertsch, P. M.: Forest sources and pathways of organic matter transport to a blackwater stream: a hydrologic approach, Biogeochemistry, 24, 1-19, 1994.

Duan, S., Bianchi, T., and Sampere, T. P.: Temporal variability in the composition and abundance of terrestrially-derived dissolved organic matter in the lower Mississippi and Pearl Rivers, Mar. Chem., 103, 172-184, doi:10.1016/j.marchem.2006.07.003, 2007.

Fasching, C., Behounek, B., Singer, G. A., and Battin, T. J.: Microbial degradation of terrigenous dissolved organic matter and potential consequences for carbon cycling in brown-water streams, Sci. Rep., 4, 4981, doi:10.1038/srep04981, 2014.

Fiebig, D. M., Lock, M. A., and Neal, C.: Soil water in the riparian zone as a source of carbon for a headwater stream, J. Hydrol., $116,217-237,1990$.

Goodman, K. J., Baker, M. A., and Wurtsbaugh, W. A.: Lakes as buffers of stream dissolved organic matter (DOM) variability: temporal patterns of DOM characteristics in mountain stream-lake systems, J. Geosphys. Res., 116, G00N02, doi:10.1029/2011JG001709, 2011.

Hanley, K., Wollheim, W. M., Salisbury, J., Huntington, T., and Aiken, G.: Controls on dissolved organic carbon quantity and chemical character in temperate rivers of North America, Global Biogeochem. Cy., 27, 492-504, doi:10.1002/gbc.20044, 2013.

Hanson, P. C., Hamilton, D. P., Stanley, E. H., Preston, N., Langman, O. C., and Kara, E. L.: Fate of allochthonous dissolved organic carbon in lakes: a quantitative approach, PLoS ONE, 6, e21884, doi:10.1371/journal.pone.0021884, 2011.

Helms, J. R., Stubbins, A., Ritchie, J. D., Minor, E. C., Kieber, D. J., and Mopper, K.: Absorption spectral slopes and slope ratios as indicators of molecular weight, source, and photobleaching of chromophoric dissolved organic matter, Limnol. Oceanogr., 53, 955-969, 2008.

Hijmans, R. J., Cameron, S. E, Parra, J. L., Jones, P. G., and Jarvis, A.: Very high resolution interpolated climate surfaces for global land areas, Int. J. Climatol., 25, 1965-1978, available at: http: //www.worldclim.org/ (last access: 2 October 2015), 2005.

Hinton, M. J., Schiff, S. L., and English, M. C.: Sources and flowpaths of dissolved organic carbon during storms in two forested watershed of the Precambrian Shield, Biogeochemistry, 41, 175197, 1998 .
Holmes, R. M., McClelland, J. W., Raymond, P. A., Frazer, B. B., Peterson, B. J., and Stieglitz, M.: Lability of DOC transported by Alaskan rivers to the arctic ocean, Geophys. Res. Lett., 35, L03402, doi:10.1029/2007g1032837, 2008.

Jaffé, R., McKnight, D., Maie, N., Cory, R., McDowell, W. H., and Campbell, J. L.: Spatial and temporal variations in DOM composition in ecosystems: The importance of long-term monitoring of optical properties, J. Geophys. Res.-Biogeo., 113, G04032, doi:10.1029/2008jg000683, 2008.

Johnson, M S., Couto, E. G. Abdo, M., and Lehmann, J.: Fluorescence index as an indicator of dissolved organic carbon quality in hydrologic flowpaths of forested tropical watersheds, Biogeochemistry, 105, 149-157, doi:10.1007/s10533-011-9595-x, 2011.

Jørgensen, L., Stedmon, C. A., Kragh, T., Markager, S., Middelboe, M., and Søndergaard, M.: Global trends in the fluorescence characteristics and distribution of marine dissolved organic matter, Mar. Chem., 126, 139-148, doi:10.1016/j.marchem.2011.05.002, 2011.

Kellerman, A. M., Kothawala, D. N., Dittmar, T., and Tranvik, L. J.: Persistence of dissolved organic matter in lakes related to its molecular characteristics, Nat. Geosci., 8, 454-457, doi:10.1038/ngeo2440, 2015.

Köhler, S. J., Kothawala, D., Futter, M. N., Liungman, O., and Tranvik, L.: In-lake processes offset increased terrestrial inputs of dissolved organic carbon and color in lakes, PLoS ONE, 8, e70598, doi:10.1371/journal.pone.0070598, 2013.

Kohn, J. M.: Carbon isotope compositions of terrestrial C3 plants as indicators of (paleo)ecology and (paleo)climate, P. Natl. Acad. Sci. USA, 107, 19691-19695, 2010.

Kothawala, D. N., Stedmon, C. A., Müller, R. A., Weyhenmeyer, G. A., Köhler, S. J., and Tranvik, L. J.: Controls of dissolved organic matter quality: Evidence from a large-scale boreal lake survey, Glob. Change Biol., 20, 1101-1114, doi:10.1111/gcb.12488, 2014.

Kothawala, D. N., Ji, X., Laudon, H., Ågren, A., Futter, M. N., Köhler, S. J., and Tranvik, L. J.: The relative influence of land cover, hydrology, and in-stream processing on the composition of dissolved organic matter in boreal streams, J. Geosphys. ResBiogeo., 120, 1491-1505, doi:10.1002/2015JG002946, 2015.

Kunz, M. J., Wuest, A., Wehrli, B., Landert, J., and Senn, D. B.: Impact of a large tropical reservoir on riverine transport of sediment, carbon and nutrients to downstream wetlands, Water Resour. Res., 47, W12531, doi:10.1029/2011WR010996, 2011.

Lambert, T., Darchambeau, F., Bouillon, S., Alhou, B., Mbega, J.-D., Teodoru, C. R., Nyoni, F. C., and Borges, A. V.: Landscape control on the spatial and temporal variability of chromophoric dissolved organic matter and dissolved organic carbon in large African rivers, Ecosystems, 18, 1224-1239, doi:10.?1007/?s10021-015-9894-5, 2015.

Lapierre, J. F. and Frenette, J. J.: Effects of macrophytes and terrestrial inputs on fluorescent dissolved organic matter in a large river system, Aquat. Sci., 71, 15-24, doi:10.1007/s00027-009-9133-2, 2009.

Lehner, B. and Döll, P.: Development and validation of a global database of lakes, reservoirs and wetlands, J. Hydrol., 296, 1-22, doi:10.1016/j.jhydrol.2004.03.028, available at: http://www. worldwildlife.org/pages/global-lakes-and-wetlands-database (last access: 15 June 2015), 2004. 
Lehner, B., Verdin, K., and Jarvis, A.: New global hydrography derived from space borne elevation data, Eos, 89, 93-94, available at: http://hydrosheds.cr.usgs.gov/index.php (last access: 15 June 2012), 2008.

Lottig, N. R., Buffam, I., and Stanley, E. H.: Comparisons of wetland and drainage lake influences on stream dissolved organic concentrations and yields in a north temperate lake-rich region, Aquat. Sci., 75, 619-630, doi:10.1007/s00027-013-0305-8, 2013.

Magadza, C.: Environmental state of Lake Kariba and Zambezi River Valley: Lessons learned and not learned, Lakes \& Reservoirs: Research \& Management, 15, 167-192, doi:10.1111/j.1440-1770.2010.00438.x, 2010.

Mann, P. J., Davydova, A., Zimov, N., Spencer, R. G. M., Davydov, S., Bulygina, E., Zimov, S., and Holmes, R. M.: Controls on the composition and lability of dissolved organic matter in Siberia's Kolyma River basin, J. Geosphys. Res., 117, G01028, doi:10.1029/2011JG001798, 2012.

Marín-Spiotta, E., Gruley, K. E., Crawford, J., Atkinson, E. E., Miesel, J. R., Greene, S., Cardona-Correa, C., and Spencer, R. G. M.: Paradigm shifts in soil organic matter research affect interpretations of aquatic carbon cycling: transcending disciplinary and ecosystem boundaries, Biogeochemistry, 117, 279297, doi:10.1007/s10533-013-9949-7, 2014.

Marwick, T., Borges, A. V., Van Acker, K., Darchambeau, F., and Bouillon, S.: Disproportionate Contribution of Riparian Inputs to Organic Carbon Pools in Freshwater Systems, Ecosystems, 17, 974-989, 2014.

Massicotte, P. and Frenette, J.-J.: Spatial connectivity in a large river system: resolving the sources and fate of dissolved organic matter, Ecol. Appl., 21, 2600-2617, 2011.

Mayaux, P., Bartholomé, E., Fritz, S., and Belward, A.: A new landcover map of Africa for the year 2000, J. Biogeogr., 31, 861-877, 2004.

Mayorga, E., Aufdenkampe, A. K., Masiello, C. A., Krusche, A. V., Hedges, J. I., Quay, P. D., Richey, J. E., and Brown, T. A.: Young organic matter as a source of carbon dioxide outgassing from Amazonian rivers, Nature, 436, 538-541, doi:10.1038/nature03880, 2005.

McKnight, D. M., Boyer, E. W., Westerhoff, P. K., Doran, P. T., Kulbe, T., and Andersen, D. T.: Spectrofluorometric characterization of dissolved organic matter for indication of precursor organic material and aromaticity, Limnol. Oceanogr., 46, 38-48, 2001.

Meybeck, M.: Riverine transport of atmospheric carbon: source, global typology and budget, Water Air Soil Pollut., 70, 443-463, 1993.

Mladenov, N, McKnight, D. M., Macko, S. A., Norris, M., Cory, R. M., and Ramberg, L.: Chemical characterization of DOM in channels of a seasonal wetland, Aquat. Sci., 69, 456-471, doi:10.1007/s00027-007-0905-2, 2007.

Moran, M. A., Sheldon, W. M., and Zepp, R. G.: Carbon loss and optical property changes during long-term photochemical and biological degradation of estuarine dissolved organic matter, Limnol. Oceanogr., 45, 1254-1264, 2000.

Neff, J. C., Finlay, J. C., Zimov, S. A., Davydov, S. P., Carrasco, J. J., Schuur, E. A. G., and Davydova, A. I.: Seasonal changes in the age and structure of dissolved organic carbon in
Siberian rivers and streams, Geophys. Res. Lett., 33, L23401, doi:10.1029/2006GL028222, 2006.

Ohno, T.: Fluorescence inner-filtering correction for determining the humification index of dissolved organic matter, Environ. Sci. Technol., 36, 742-746, doi:10.1021/Es0155276, 2002.

Parks, S. J. and Baker, L. A.: Sources and transport of organic carbon in an Arizona river-reservoir system, Water Resour., 31, 1751-1759, 1997.

Raymond, P. A., Saiers, J. E., and Sobczak W. V.: Hydrological and biogeochemical controls on watershed dissolved organic matter transport: pulse-shunt concept, Ecology, 97, 5-16, doi:10.1890/14-1684.1, 2016.

Schlesinger, W. H. and Melack, J. M.: Transport of organic carbon in the world's rivers, Tellus, 33, 172-187, 1981.

Spencer, R. G. M., Stubbins, A., Hernes, P. J., Baker, A., Mopper, K., Aufdenkampe, A. K., Dyda, R. Y., Mwamba, V. L., Mangangu, A. M., Wabakanghanzi, J. N., and Six, J.: Photochemical degradation of dissolved organic matter and dissolved lignin phenols from the Congo River, J. Geophys. Res.-Biogeo., 114, G03010, doi:10.1029/2009jg000968, 2009.

Stackpoole, S. M., Stets, E. G., and Striegl, R. G.: The impact of climate and reservoirs on longitudinal riverine carbon fluxes from two major watersheds in the Central and Intermontane West, J. Geophys. Res-Biogeo., 119, 848-863, doi:10.1002/2013JG002496, 2014.

Stedmon, C. A. and Markager, S.: Resolving the variability in DOM fluorescence in a temperate estuary and its catchment unsing PARAFAC, Limnol. Oceanogr., 50, 686-697, 2005.

Stedmon, C. A. and Bro, R.: Characterizing dissolved organic matter fluorescence with parallel factor analysis: a tutorial, Limnol Oceanogr.-Meth., 6, 572-579, 2008.

Stedmon, C. A., Markager, S., and Bro, R.: Tracing dissolved organic matter in aquatic environments using a new approach to fluorescence spectroscopy, Mar. Chem., 82, 239-254, doi:10.1016/s0304-4203(03)00072-0, 2003.

Striegl, R. S., Aiken, G. R., Domblaser, M. M., Raymond, P. A., and Wickland, K. P.: A decrease in discharge-normalized DOC export by the Yukon River during summer through autumn, Geophys. Res. Lett., 32, L21413, doi:10.1029/2005GL024413, 2005.

Tamooh, F., Van den Meersche, K., Meysman, F., Marwick, T. R., Borges, A. V., Merckx, R., Dehairs, F., Schmidt, S., Nyunja, J., and Bouillon, S.: Distribution and origin of suspended matter and organic carbon pools in the Tana River Basin, Kenya, Biogeosciences, 9, 2905-2920, doi:10.5194/bg-9-2905-2012, 2012.

Teodoru, C. R., Nyoni, F. C., Borges, A. V., Darchambeau, F., Nyambe, I., and Bouillon, S.: Dynamics of greenhouse gases $\left(\mathrm{CO}_{2}, \mathrm{CH}_{4}, \mathrm{~N}_{2} \mathrm{O}\right)$ along the Zambezi River and major tributaries, and their importance in the riverine carbon budget, Biogeosciences, 12, 2431-2453, doi:10.5194/bg-12-2431-2015, 2015.

von Wachenfekdt, E. and Tranvik, L. J.: Sedimentation in Boreal lakes - the role of flocculation of allochthonous dissolved organic matter in the water column, Ecosystems, 11, 803-814, doi:10.1007/s10021-008-9162-z, 2008.

Walker, S. A., Amon, R. M., and Stedmon, C. A.: Variations in highlatitude riverine fluorescent dissolved organic matter: A comparison of large Arctic rivers, J. Geosphys. Res-Biogeo., 118, 16891702, doi:10.1002/2013JG002320, 2013.

Ward, N. D., Keil, R. G., Medeiros, P. M., Brito, D. C., Cunha, A. C., Dittmar, T., Yager, P. L., Krusche, A. V., and Richey, J. 
E.: Degradation of terrestrially derived macromolecules in the Amazon River, Nat. Geosci., 6, 530-533, doi:10.1038/ngeo1817, 2013.

Ward, N. D., Krusche, A. V., Sawakuchi, H. O., Brito, D. C., Cunha, A. C., Moura, J. M. S., da Silva, R., Keil, R. G., and Richey, J. E.: The compositional evolution of dissolved and particulate organic matter along the lower Amazon River-Óbidos to the ocean, Mar. Chem., 177, 244-256, doi.org/10.1016/j.marchem.2015.06.013, 2015.

Weishaar, J. L., Aiken, G. R., Bergamaschi, B. A., Fram, M. S., Fujii, R., and Mopper, K.: Evaluation of specific ultraviolet absorbance as an indicator of the chemical composition and reactivity of dissolved organic carbon, Environ. Sci. Technol., 37, 47024708, doi:10.1021/es030360x, 2003.

Wellington, J. H.: Southern Africa - a Geographic Study, vol. 1, Physical Geography, Cambridge University Press, Cambridge, 528 pp., 1955.

Weyhenmeyer, G. A., Fröberg, M., Karltun, E., Khalili, M., Kothawala, D., Temnerud, J., and Tranvik, L. J.: Selective decay of terrestrial organic carbon during transport from land to sea, Glob. Change Biol., 18, 349-355, doi:10.1111/j.13652486.2011.02544.x, 2012.

Winterdahl, M., Erlandsson, M., Futter, M. N., Weyhenmeyer, G. A., and Bishop, K.: Intra-annual variability of organic carbon concentrations in running waters: Drivers along a climatic gradient, Global Biogeochem. Cy., 28, 451-464, doi:10.1002/2013GB004770, 2014.
Yamashita, Y., Jaffé, R., Maie, N., and Tanoue, E.: Assessing the dynamics of dissolved organic matter (DOM) in coastal environments by excitation emission matrix fluorescence and parallel factor analysis (EEM-PARAFAC), Limnol. Oceanogr., 53, 19001908, 2008.

Yamashita, Y., Scinto, L. J., Maie, N., and Jaffé, R.: Dissolved organic matter characteristics across a subtropical wetland's landscape: application of optical properties in the assessment of environmental dynamics, Ecosystems, 13, 1006-1019, doi:10.1007/s10021-010-9370-1, 2010.

Zepp, R. G., Sheldon, W. M., and Moran, M. A.: Dissolved organic fluorophores in southeastern US coastal waters: correction method for eliminating Rayleigh and Raman scattering peaks in excitation-emission matrices, Mar. Chem., 89, 15-36, doi:10.1016/j.marchem.2004.02.006, 2004.

Zurbrügg, R., Suter, S., Lehmann, M. F., Wehrli, B., and Senn, D. B.: Organic carbon and nitrogen export from a tropical dam-impacted floodplain system, Biogeosciences, 10, 23-38, doi:10.5194/bg-10-23-2013, 2013. 